\title{
THREE INTELLIGENCE METHODOLOGIES FOR BORDER DEFENCE AND BORDER SECURITY
}

\author{
Dr Glen Segell \\ Director: Institute of Security Policy \\ United Kingdom
}

\begin{abstract}
The main security problem that any state faces today is protecting its citizens in countering organised crime and terrorism. Wars between states are less frequent than in previous eras. Border defence and border security are distinct missions requiring different forces with different training and different equipment. Border defence is predominately against the armed forces of other states requiring tanks, aircraft and ships. Traditionally, border security includes the mission roles of immigration, crime, agriculture, finance, disease control and terrorism. Intelligence gathering and analysis using three methodologies - trends and patterns, frequency, and probability - provides a solution to the large and expensive armed forces for territorial border defence and defines the ability to succeed in border security.
\end{abstract}

\section{Introduction}

The main security problem that any state faces today is protecting its citizens in countering organised crime and terrorism. Such a security problem cannot be resolved through defence of the territorial demarcation of the sovereign state. Organised crime and terrorists operate with impunity across territorial borders that in today's age of globalisation are no more than drawn lines on maps. This demise of territoriality in issues of security brings into question the role of the armed forces in defending citizens of the state. This problem is accentuated by the increasing costs in the research, development and production of weaponry associated with longer procurement lead-in times. The armed forces of states are thus not equipped to defend against the main threats to citizens being terrorism and organised crime.

Initial research by Clauser and Weir (1975:4) has been furthered by 
Johnston (2005:12) in identifying various methods and a taxonomy for intelligence analysis. Of these there are three intelligence methodologies applicable to this article - trends and patterns, frequency, and probability. These offer a solution to such border defence and border security problems by using the role of analysis explained by Ermarth (1988:7-11). At any given stage all three may be utilized simultaneously or separately. Kahn (2001) has shown that each methodology has its strengths and weaknesses and that each has arisen from specific historical practice. The intelligence methodologies do not exist in a void. Intelligence analysis can only succeed if it can be acted upon. This means there must be operational viability. Essential to any success is the structure of each intelligence agency and its organizational relations with other government and non-government entities domestically, regionally and globally. Intelligence gathering and analysis in the three methodologies is both ad hoc and specifically requiring a constant two-way street for the input of further data and the clarification, questioning and revision of existing data.

The necessity of separating border defence and border security is a salient issue to address when deliberating the intelligence methodologies as a solution to both. Border defence is the mission role of the armed forces of territorial sovereign boundaries predominately against the armed forces of other states. The problem in the $21^{\text {st }}$ Century is that border defence capabilities are often measured in tanks, aircraft, ships and number of troops whose cost escalates with new technology and with increasingly longer procurement lead-in times. Most of this equipment is superfluous in the $21^{\text {st }}$ century as the majority of wars are not between states but within states. Few if any states are capable or have the intention of invading or occupying other states. The example of the Iraqi invasion of Kuwait 1990 shows the ability of a powerful state to invade another state with little resistance where the consequential world condemnation led to immediate and decisive military action to reinstate Kuwait sovereignty. Further, the above problem of border defence is accentuated by the phenomena of globalisation characterised by diminished territorial demarcation. This leads to questioning the viability of defence(s) emphasised on territorial demarcations where organised crime and terrorists operate with impunity across territorial demarcations. Jensen (2004:247-256) has noted that in order to maintain a secure state with closed borders it could only be at the expense of civil liberties.

Consequently in an era of globalisation heavy investment of equipment and manpower in territorial border defence is less relevant than in previous epochs. This is accentuated by an increase in security issues facing citizens within state borders such as the rise in crime and terrorism. Hence arises the significance of 
border security over that of border defence in the role of the state defending its citizens. The missions of borders security are those defined, by Adelman (2002:514), as including issues of refugees to which could be added illegal immigration, organised crime in drug and human trafficking, finance such as money counterfeiting and laundering, control of agricultural issues such as 'mad cow', control of human diseases such as SARS and counter-terrorism. Pickering (2004:211-226) concludes that police or para-military forces in a domestic context are the forces to counter these and often rely on relations with local communities to be at the forefront of implementing such state security and not a state's armed forces.

There is a vast array of theoretical literature and case studies debating these problems of border defence and border security. None of these, including the historical luminaries such as Clausewitz (Howard and Parett 1989) and Sun-Tsu (Barrio 2001) or contemporary experts such as Pierik (2003) and Mbuh (2004), have suggested the aforementioned inspiring solution of intelligence methodologies that could be applied to border defence and to border security in the age of globalisation typified by open borders or artificial borders.

Open borders is exampled through Treaty such as in the formation of the European Union (EU) that guarantees the freedom of the movement of goods and people to all individuals of the European Union. The role of armed forces is minimised given that there are no borders to patrol nor are there any border crossings between the European Union (EU) member states. Artificial borders is exampled in Africa as a consequence of colonisation by external powers and decolonisation retaining the sanctity of these territorial borders that took little if any consideration to local or ethnic heritage. The role of armed forces is minimised given that troops are both sides of these borders may be family relatives reluctant to engage in combat with each other and frequently are not even aware of where the state border lies. Henceforth this article will discuss the significance and value of the aforementioned intelligence methodologies.

\section{The intelligence methodology of trends and patterns}

In the mission of intelligence the methodology of using trends and patterns in data gathering and analysis has been shown historically by Agrell and Huldt (1983:3) to be the most significant for territorial demarcation defence (border defence). Austin and Rankov (1995:5-6) note that this methodology of trends and patterns is not a new methodology having been the prevailing one for centuries in diplomatic analysis in preparation or prevention of conflict and war and by the armed forces once war has commenced. Dvornik (1974) has confirmed this 
providing examples from The Ancient Near East, Persia, Greece, Rome, Byzantium, the Arab Muslim Empires, the Mongol Empire, and China. Sheldon (2002:34) in seminal research on espionage in the ancient world has elaborated that the methodology arose with the need to defend a fixed point, be that a city or a line on a battlefield or at sea. Associated conflicts through the ages included the citystates of the Greek era, monarchical fiefdoms and castles during the Middle Ages, states since the Treaty of Westphalia (1648) and the Cold War. This was a period of warfare where armies, such as those in the feudal period, found it comparatively easy to defend from the high ground or from a fortified position and away from the rising sun. Navies could similarly defend an island, straight, estuary or a territory demarcated by a wide river. This is exampled by the navies of the European Great Powers who controlled the trading routes of their global empires. Naturally such geographical advantages went hand-in-hand with technological advantage such as gunpowder, numerical supremacy, training, tactics and strategy.

The methodology of trends and patterns, however, has not been applied as a solution to the problem of expensive equipment and long procurement lead-in times for the armed forces in border defence in the $21^{\text {st }}$ Century period of globalisation. This period of globalisation is typified more with arms control and disarmament rather than escalating arms procurement. The intelligence methodology needs to assist such processes. Further this intelligence methodology has not been previously applied by the armed forces for use in support missions of the aforementioned border security missions short of territorial demarcation. This is acknowledged in primary sources read in the Public Record Office (Kew, England) in the folder sections: Security Service personal files relating to individuals (KV 2), subject files (KV 3), policy files (KV 4), organisation files (KV 5) and list files (KV 6). This has not been repeated in any identifiable secondary literature.

The intelligence methodology, in adapting to globalisation and in evaluating a state's intent and capability (trends and patterns) emerges from the evolution of nuclear strategy in the Cold War explained by Freedman (1981:129) and its proxy local wars such as Vietnam detailed by Maclean (1981:209). The Cold War and its proxy wars show that numerical and qualitative strength through aircraft, tanks and ships do not necessarily guarantee the territorial defence of a state. This is further epitomized by Carter (2001:5-23) who gives post-Cold War examples of organisations such as Al Qaeda and the Chechen rebels that show impunity for territorial defences and challenge the very architecture of government. Such lessons highlight the dichotomy inherent in the problem of cost and long procurement lead-in times for border defence. This is that more is not always better. 


\section{5}

Hence the methodology of intelligence is applicable for border defence to resolve the problems of increasing costs, increasing procurement lead-in times and the reduced need for border defences in the age of globalisation. This methodology of trends and patterns is the most applicable for state-to-state conflicts in monitoring and ascertaining intentions of potential adversary states based upon the build-up of capabilities and/or gathering of forces. In doing so intelligence data gathering and analysis of trends and patterns or intent and capability is a basic element of diplomacy to ameliorate conflict and should diplomacy fail it also serves a basic element in the preparation for war. Diplomacy based on accurate information can ameliorate a conflict or deter an aggressor negating the necessity to invest in expensive armed forces with long procurement lead-in times.

Neilson and McKercher (1992:3-9) describe how this methodology is also the primary methodology employed by military intelligence organisations for operational analysis on the tactical level of deploying and focusing forces as when and they would be required on the battlefield. This is defined, for example, in the US National Security Act of 1947 as quoted in Cumming and Todd Masse (2004:42). More recently in the $21^{\text {st }}$ Century such an intelligence methodology would alleviate the need to duplicate forces, often assigned to more than one political purpose, for instance British forces to the North Atlantic Treaty Organisation (NATO) and the $\mathrm{EU}$, given the advent of network centric warfare and rapid deployment forces. Successful intelligence analysis of the trends and patterns in the tactics and strategy of an adversaries forces, once an armed conflict has commenced, could determine when and where an opponent would strike and indeed the location of its forces enabling preemptive strikes.

Such an intelligence methodology for border defence has also become ever increasingly more significant with the advent of aerial warfare capability, especially since the World War II. Hand-in-hand with aerial combat came surveillance, be it aircraft or satellite, assisting and furthering intelligence data gathering and analysis of potential adversaries through trends and patterns. The enhanced intelligence gathering capability, however, came with more devastating areal weaponry. Aerial warfare took the battle across space and time involving both civilian and military targets. This was associated with the first of the notion 'weapon of mass destruction' to describe aerial bombardment of cities in World War II with the strategic thinking from the 1930s that the 'bomber would always get through' as noted by Bialer (1980:1). The concept later included the advent of missiles and nuclear weapons during the Cold War - until today there is no $100 \%$ viable anti-missile defence system. Thus territorial border defence became not just the ability to defend a point or a line but also encompasses diplomacy and deterrence that go hand-in-hand as 
tools of dissuading an adversary from launching an offensive. Duffield (2002:153165 ) in researching this suggests that massive damage could be inflicted in retribution for any attack with war as a network enterprise of intelligence.

From the ability to focus such massive fire-power across time and space came the necessity to focus intelligence on the causes of conflict leading to war in order to prevent the war. Such causes were often related to territory, resources, monarchical family feuds, ideology or religion. Mackmurdo (2004:23-25) notes that getting the facts or data gathering focused on these as causes for analysis of intent and capability. In the $21^{\text {st }}$ Century such analysis can be utilised in determining border defence weapon procurement. For example, where state leaders make statements of intent that could be construed as bellicose then other states would consider the ability and capability of that state to carry out the intent. Consequently they would prepare for war, form alliances or take measures to deter or prevent a conflict. In this intelligence is essential to determine the actual buildup of military capability as a clear indication to prepare for war. In some cases bluff and brinkmanship could win an issue or conflict without having to resort to the use of armed force.

Despite the ability to strike far behind sovereign borders and even across the globe, the vulnerability of a sovereign state's territorial borders remains to its neighbours. This gives decision-makers in most states, including Southern Africa, a focal point on who to defend against and on whom to gather data and effect intelligence. When political-military elites procure equipment for border defence forces they have to juggle decision-making on the size, structure and resources (human and equipment) in conjunction with the intent and capability of neighbouring states. Kirkpatrick (2004) has expanded this list to include other considerations such as the mighty military-industrial complexes, employment, status, and the already mentioned insurance policy syndrome. Effectively balancing these considerations is determined by effective intelligence on the intent and capability of neighbouring states using the methodology of trends and patterns.

The strength of the use of trends and patterns in data gathering and analysis and its continuance as the main methodology as a solution for border defence also lies in its value for the continuity in training and in staff changeover. The period of post World War II de-colonization increased the number of sovereign states eight fold to the current almost 200 member states of the United Nations. This necessitates an enormous effort for intelligence agencies in gathering data about each of these states' intent and capabilities, be it military, economic, human or otherwise. New staff in the intelligence agencies can be quickly brought to focus on 
gathering such data. Such staff could have language skills and/or education in documentation reading such as degrees in history, English, politics or sociology. Frequently, open sources such as newspapers, radio and television can provide the broad picture of the trends and patterns (intent/capability) in any situation. More experienced staff, often fewer in number, can be employed in analysis by looking for newly emerging trends and patterns or irregularities in existing trends and patterns. Even fewer staff, the seasoned specialists, can be involved in the gathering and analysis of specific cases with cause for concern such as rogue or failed states or non-state entities that threaten states such as terrorism and warlordism.

It follows that accurate intelligence prediction and forecasting in trends and patterns will determine the type and quantity of weaponry procured by a state and hence the size and structure of its armed forces. The more accurate the intelligence analysis on intent and capability of any potential adversary the more a state can rely on small, elite and mobile forces with highly accurate weaponry to show that it 'means business' to give credibility to diplomacy, to ameliorate a dispute, to effect det errence, and even to project power. This then is a suggested solution to the problem of border defence in the $21^{\text {st }}$ Century with the advent of globalisation associated with open and artificial borders and ever increasing costs of weapon procurement associated with long procurement lead-in times.

\section{Border defence weapon procurement and intelligence analysis}

Integral to using this intelligence analysis as a solution to the contemporary problems posed in border defence is utilising the findings to construct new tactics and strategies for the armed forces. Determining weapon procurement based upon the intelligence analysis would be integral in formulating such tactics and strategies. Such tactics and strategy and the weapon procurement to suit them would be reflected in active defence, active offence, offence posturing, and the credibility of diplomats. Inherent to the trends and patterns intelligence methodology would be the problem of a subsequent change in regime or externalisation of a domestic issue of a state under evaluation. This would change a capability analysis of another state into an analysis based on intent or threat. The intelligence analysis would focus on how the availability of weapons or latent capability could influence intent unwittingly instead of intent being the driving force to acquire capability for specific tasks and missions. Intelligence analysis of this kind would assist a state feeling threatened, due to a another states change in regime, to alleviate its insecurity fears due to the unknown elements of intent and hence promote diplomatic exchanges to ameliorate any escalation towards conflict. In this intelligence analysis would be in lieu of an arms race. 
Further the solution of intelligence analysis for the problems of border defence weapons procurement in the age of globalisation is even more pressing given that most states in the world procure most of their weapons off-the-shelf from other states. Many of these weapons are suited for the manufacturing states' needs and not always for the second states requirements. This generates a capability that has little or no practicality to meet local defence and security needs. Intelligence analysis could resolve this superfluous procurement. To this end, Ackleson (2003:573-581) notes that the worlds largest military spender and procurer of the most technologically sophisticated weapons, the United States, procures weapons for power projection and not based on territorial border threats for her land borders with Canada and Mexico where such weaponry is not suited to counter the threats of terrorism or even deter drug and human traffickers.

States in Western Europe and now Central and Eastern Europe have learnt the lessons of two World Wars and the Cold War and hence have adopted border defence equipment procurement based upon trans-national collaborative manufacture. Such collaboration procurement aims to lock together neighbouring states' defence-industries in joint production lines and ensure regionally equality in weaponry. The philosophy is that neighbouring states will think twice about going to war if they know their neighbours' capabilities, which are the same as their own, and if they rely upon each other for production and spare parts. Hence the actual weapon systems are rarely if ever aimed at any specific adversaries' capabilities and are not technologically state-of-the-art. This weaponry is cheaper than weaponry bought off-the-shelf from from the United States due to the economy of scale of procurement from $3-5$ states. Thus while states in Africa, Asia and Latin America seeks the most sophisticated weaponry for border defence this weaponry is supplied by states that no longer use this weaponry to defend their own borders and hence is rarely of ever suited to meet the actual requirements.

The intelligence methodology of trends and patterns assists weapon developing and production states such as the United States, and members of the the European Union when thinking through the various procurement options to counter adversaries. The intelligence analysis focusses on developing tactics and strategy in conjunction with such weapon development acknowledging that when intent and capability of adversaries is well known that it offers a solution to the problem of procurement of expensive weapons with long lead-in times of procurement. The emerging strategy, for example, of the United Kingdom is to rely on NATO as a forward defence, the EU as collective defence and its island insularity, while the United States knows that it can only defend its territorial borders by redefining their 


\section{9}

location. In doing so weapons procurement and indeed the activities of the armed forces have been supplemented by new initiatives relying on intelligence and policing.

One such initiative of the United States is the Container Security Initiative (CSI) whose workings have been intensively analysed by Roach (2003:241-361). He describes the CSI strategy as being deployed by United States Customs and Homeland Security inspectors outside of the borders of the United States at the point of departure of large container ships destined for the United States. They work with local officials determining the safety of the contents of the containers. This principle has also been engaged with passenger aircraft destined for the United States. The details of passengers are entered into the airline computer systems on check-in at the foreign destination and then cross-referenced with Homeland Security systems. Undesirable persons are prevented from boarding the aircraft. Both such initiatives do not require any form of weapons procurement, but are actively protecting the borders of the United States through the gathering and analysis of information. A more pro-active initiative is the Proliferation Security Initiative (PSI) where the United States and co-operating states seek to board and search ships on the high seas that might be conveying cargoes of weaponry as part of a counter-proliferation effort. The origins and destinations might be any state and hence the initiative relies on the global gathering and analysis of information.

Such missions and solutions using intelligence show how border defence missions are transitioning into border security missions. There are numerous publications exampling this transition where the seminal have been McCullough (2004) and Shultz et al (2004). These provide examples of how the United States and European states are using the intelligence methodology of trends and patterns to determine: firstly, threat analysis supplanted by capability analysis; secondly, reliance on these to effect the offensive is the best form of the defensive namely preemptive or preventive war; thirdly, to implement dissuasion as a valid method to link defence, deterrence and diplomacy; and lastly, to gain asymmetrical supremacy. In doing so the intelligence methodology has shown the ability to reduce the burden on heavy machinery type weaponry with large armed forces. Small, versatile, mobile, specialist response forces with network centric warfare capability is a winning method!

The solution of intelligence analysis to such problems of border defence and weapons procurement should be considered by African states as well. Orogun (2003:283-313) and Cliffe (1999:89-111) give perspective on African wars that show that for too long African states have been procurer of weaponry designed and 
manufactured for other local or regional considerations. The risks of procurement off-the-shelf are well known, including: not suiting local needs sufficiently; that procurement or support might be interrupted if a foreign contractor had other priorities or if its government disagreed with some local policy; and issues of spares. Domestic self-sufficiency is not an option, even for the hegemonic powers. The lessons are evident. Intelligence analysis shows that it is often the individual soldier with an assault rifle that is best suited to defend a state's border. In procurement it should be remembered that the Zulu beat the British at Islandwana with assegai against rifle while the weapon of choice between the Hutu and Tutsi in Rwanda was the machete. These conflicts show that wars can be won and lost without the need for expensive MIG and Mirage aircraft or indeed main battle tanks.

This is not to negate the need for sophisticated aircraft and ships that are needed for coastal 'air-sea rescue' and land-mine resistant armoured personnel carriers capable of high-speed dashes across unpaved bush-land. The lessons of the European Union's Common Foreign and Security Policy (CFSP) and Security and Defence Policy (ESDP) inserted into the concept of the Africa Union, show that an agenda can be constructed on how neighbouring states can jointly determine their procurement and training to suit regional defence needs. Such political-military acumen is founded on the economic principle of economics of scale in trans-national collaboration, the sharing of resources regionally and the opening of neighbouring borders.

Essential to this model is the element of trust that relies on validated information. Predominant in building domestic trust and regional trust is confidence in knowing that your population and neighbours are not posing threats to each other or to stable governance. This requires constant and effective intelligence. With time all states in a region would not seek a large army for domestic purposes and would hence engage in effective and stable domestic governance. In turn this would generate regional stability furthered through regional collective defence alliances the concept of mutual defence. As the case of the European Union has shown this has turned the primary mission of border defence into a task of intelligence rather than a task of armed force. The dominant salient issue is that of the security of individuals in combating organised crime and terrorism rather than the defence of state borders.

\section{Border security distinct from border defence}

The above debate has shown that defence of territorially demarcated 
borders has become less significant while border security issues have become more pressing. The reduced restriction on the movement of goods and people due to globalisation typified by global flows of finance and communication has given rise to this predominance of border security over that of border defence. This is exampled by the European Union that has shown that the opening of state borders to the free flow of goods and people is characteristic of the growth in regional cooperation and of mutual defence. It is also exampled in Africa by artificial borders since the above debate on border defence shows that it is not always possible to procure weapons to defend lines drawn on a map as a result of political arrangements. These factors and the diminishing role of the armed forces in the patrol and protection of territorially demarcated borders generates the next element of the problem that border defence is facing at the onset of the $21^{\text {st }}$ Century.

This problem is that border security is not about lines on maps nor is it about defending a territorially demarcated state. Border security is about the security of individuals. It is about a state protecting its citizens against non-state entities sometimes supported by other states exampled by organised crime, terrorism, illegal immigration, drug trafficking and money laundering, and warlordism to name just a few. Governments, their armed forces and police are often financially stretched, with human and equipment resource constrained and not suited to the numerous tasks, and time limited to cover and counter the diverse wide range of threats posed against citizens.

The solution to such security problems is therefore for intelligence gathering and analysis to ascertain the nature and severity of the threat, the source of the threat and hence the best means of countering, deterring, preventing or preempting the threat. For example there is clearly a difference between petty crime such as shoplifting and organised crime such as money counterfeiting. Global cooperation through the exchange of information through such organisations as Interpol, regionally through such organisations as EUROPOL, or bi-laterally between states, shows that the success of border security is through intelligence gathering and analysis. The most relevant intelligence methodology is that of trends and patterns but in conjunction with two other methodologies that will be detailed later in this article (frequency and probability).

The application of the intelligence methodology of trends and patterns, to determine weapons procurement and the shape and size of the forces to handle the threat, varies from state to state. Such variance is due to the complexity of border security pertaining to the local environment in which individuals live and their motives and goals. Some regions will have warm climates conducive to drug 
cultivation. The advent of this trend and pattern in illicit activity would require procurement of helicopters and light aircraft to spray such cultivation. Other regions will have deserts and mountainous regions that could harbour terrorist training camps. To counter such a trend and pattern of terrorist training would require elite para-military forces brought to bear with precise satellite surveillance and locating. This diversity of local environments and hence the utilisation of the intelligence analysis in an operational context highlights the different equipment and force requirements for border security from state to sate. It also highlights the growing contextual differences between border defence and border security.

Border security and border defence could be undertaken by the same force structure with the same weaponry prior to the increase in the number of sovereign states arising from the Versailles Agreement after World War I and due to decolonisation. It was during this period that world-wide the concept of citizenship could only be defined in relation to sovereignty and if the latter was not wide-spread then it follows that neither was the former. Notably there was little if any care about the movement of individuals until after World War II associated with the advent of mass taxation, the welfare state, state funded mass education and mass health services. Indeed travel documents such as passports differentiating citizens of one state from another are predominately a twentieth century phenomena associated with the technological development of mass tourist transport. Essentially in such a world defence of the state's borders was considered the security of individuals in the collective sense. Hence a state could entrust a singular entity 'the military' with the protection of all its resources on behalf of subjects of the crown in the name of the crown. This was predominately through defence of the territorial demarcation of the sovereign state.

The determination of border security missions distinct from border defence missions arose with population movements, with technological innovations and with the growth in the number of sovereign states. The combination of these factors gave necessity to specific roles, tasks, equipment and force structures to monitor and inhibit the flow of people crossing state borders as part of the protection of the state for its populace, resources, values and governance. Such border security roles and tasks were acceptable given the Cold War and with the advent of the welfare state. The former for security and ideological reasons and the later for economic reasons to ensure that only citizens that paid taxes to a specific state would be the legitimate recipients of that states' benefits such as education and health services.

The Cold War international environment made it both desirable and acceptable to utilise the armed forces of states to establish fences and walls between 
states or landmine fields and to enforce border crossings of individuals authorised only with legalised and legitimate documentation. Hence the armed forces became the predominate method to protect a state and its atizens through territorial demarcations. Security of individuals within states was entrusted to police, paramilitary forces and internal security organisations.

Progressively since the end of the Cold War border defence and border security has become ess associated with territorial demarcation as noted in the debate above on the characteristics of open and artificial borders. Even sovereign borders have become less significant where trading blocs have been formed such as in Europe (EU) and North America (North American Free Trade Agreement NAFTA) and where traditional community ties have forsaken lines on maps such as in Africa and Asia. It is understood that the Cold War is over and in many instances it is no longer ideologically or financially possible to maintain physical obstacles to the movement of individuals. Globalisation associated with technological innovation permits commerce and communication to be undertaken by electronic means such as the Internet that is not restricted by territorial sovereignty. It is therefore not surprising that Paul and Ripsman (2004:355-380) have questioned national security state and indeed the role of armed forces in such an age of globalisation.

It follows that in the $21^{\text {st }}$ Century world, the mission roles of border defence and border security are distinctly two different missions requiring different forces, equipment and training. Clearly the armed forces of states tasked with territorial style defence are not suitably trained nor equipped to tackle non-state organised crime and terrorists who train in one country and operate and attack in another. The openness and freedom of movement of goods and people has been abused by criminal elements and by terrorist movements. The main method towards combating this organised crime and terrorism is the sharing of information between local police forces on a global basis.

Consequently, the armed forces of states have been modified to suit the new border defence mission. Border defence requires co-operation between neighbouring states in building confidence to disarm and in intelligence gathering and analysis for diplomacy and deterrence to ensure that armed conflict does not arise. A state needs only small elite and mobile forces with highly accurate weaponry to show that it 'means business' to give credibility to such diplomacy. Regiments of infantry, Presidential Guards, nuclear submarines and long-range bombers are obsolete for $21^{\text {st }}$ Century border security missions. However, as an insurance policy such forces are still retained, usually in barracks and occasionally let out on parade grounds. Given time, the ageing of equipment and with confidence 
building between neighbours such an insurance policy will also fall by the wayside.

Further the operational implementation of intelligence analysis for border security is by specialist security forces and local police. In some cases there will be a need for border defence and border security to co-operate, for example, in countering state sponsored terrorism, as demonstrated in the 9/11 (2001) terrorist attacks and the US campaign against Afghanistan in harbouring and sponsoring terrorism. To be sure the 9/11 example highlights the difficulty posed to both border security and border defence when 19 citizens of a third country, Saudi Arabia, used hijacked commercial aircraft as if they were cruise missiles in attacking two civilian targets and the military headquarters of a superpower. The only method for successful operations against such threats would be to determine who was a terrorist prior to boarding the aircraft. This is a mission for intelligence gathering and analysis. It is not an easy task given that there might not be an emerging trend or a pattern identifiable about individual terrorists. Hence the intelligence methodology of trends and patterns would need to be supplemented by the intelligence methodologies of frequency and patterns.

\section{Additional intelligence methodologies applicable to border security}

The usage of the intelligence methodology of trends and patterns for border security poses obstacles not faced with usage of the same intelligence methodology for border defence. This is especially in the surveillance of individuals and the legality in doing so. Further the identification and surveillance of trends and patterns of individual criminals and terrorists cannot guarantee 100 per cent success given the unpredictable nature of the human element and given the very restricted time-space of detecting the potential for illicit or terrorism activity and in apprehending the perpetrator. Even in those countries that have mandatory ID documents, authorities have found it hard to monitor and restrict movement of specific individuals as ID documentation forgeries are common place. Nevertheless the intelligence methodology of trends and patterns is still the most applicable in border security relying on the gathering and shifting through of large amounts of information. The success of this is most obvious in long term operations against organised criminal and terrorism networks already identified. This is through the construction of scenarios and planning to implement operations such as those undertaken by the European Border Guard Agency. It is, however, somewhat limited for the short term application to individual criminals and terrorists unless specific information becomes available to identify an imminent threat. 
In order for this intelligence methodology to be successful in countering illicit and terrorist activities the intelligence services need to monitor all individuals within a state and their transits between states. Inherent to the debate on open and artificial borders, for example in the European Union, is the basic right of the freedom of movement of individuals amongst and between 25 sovereign member states, including the right to work and vote in states other than the citizenship of the individual. Another example is the United States that has constitutional rights for the individual that restricts the state from monitoring of individuals without a court order. Such examples reveal that border security intelligence is dichotomous with democracy. Reconciling democratic freedom, legality and technical difficulties with abuse by criminal elements and those subversive to state governments, such as warlords and terrorists, could entail curtailing democratic freedom.

In reconciling this dichotomy of the 'democratic dilemma' border security intelligence services implement the methodology of trends and patterns by analysing information already provided by individuals. This $\dot{\mathrm{s}}$ achieved in analysing the available data by means of linking computer databases to find the 'odd one out'. The 'odd one out' might be an illegal immigrant, a criminal or a terrorist. Such an 'odd one out' can be found, for example, in houses without a TV license, whose residents might not be on any medical register, whose residents are not on the electoral register, and whose residents only pay cash for their utility bills of water and electricity. Despite the use of this information the average person will not be investigated as the goal is to detect a trend or pattern. This also reconciles the concerns of privacy of citizens, data protection, copyright laws and intellectual property rights. This methodology is actively employed by police forces on a daily basis in crime detection at all levels. The sharing of such information on a transnational basis, through EUROPOL for example, enables the construction of a comprehensive database on the trends and patterns of an entire population or a specific segment thereof to spot the 'odd one out'.

For example, the border security intelligence methodology of trends and patterns within the European Union is enacted through EURPOL co-ordinated databases in a legalistic fashion of information already available to EU member states police authorities. The majority of employment is regulated by a PAYE tax system requiring a unique PAYE number issued to individuals based on their proven legitimate right of residence and work such as birth and/or Visa. The same number is also therefore used when a person is unemployed and requests state benefits. Similarly, the United States uses a Social Security Number for this purpose. Furthermore, European Union states operate a national health and welfare system that requires another unique 'ID number' also based on the proven legitimate right 
of residence and work. Various mechanisms are in place to cross-reference these systems with other necessities in a Western world context such as bank accounts, credit cards, driving licenses, store loyalty cards and utility services such as gas, electricity and water. For example to ascertain that there is no tax evasion, to pay welfare benefit directly into a bank account via the BACS system or to generate a credit card limit for a person at a specific address based upon level of income and outgoing monthly expenditure.

Further data is also gathered from Visa and work permit applications such as the European Schengen Visa programme which is also monitored by EUROPOL. With a Schengen Visa, a person may enter one country and travel freely throughout the Schengen zone. Internal border controls have disappeared; there are no or few stops and checks. This means that internal air, road and train travel are handled as domestic trips. The Schengen Visa was implemented in 1995 when seven member countries of the European Union agreed on a common Visa policy. This policy provides for police and judicial co-operation; and linked up with a centralised computer system that pools information about cross-border crime - in particular the smuggling of drugs and the arrival of illegal immigrants. Today the 15 Schengen countries are: Austria, Belgium, Denmark, Finland, France, Germany, Iceland, Italy, Greece, Luxembourg, Netherlands, Norway, Portugal, Spain and Sweden. All these countries except Norway and Iceland are European Union members.

The average person normally has no qualms about providing personal information when completing application forms for local services or for Visa applications to any country. Indeed it is part and parcel of everyday life to obtain the many essential services of a modern world where application forms frequently request the same basic information such as name, age, data and place of birth and current place of residence. Some such as diving license and Visa also require photographs of the person. It is only the person who has something to hide that will become the 'odd one out' in the trend and pattern. The police and/or security forces will investigate the person who has applied for some but not all the basic cards, services or numbers or the person who provides conflicting information. The lessons are clear that as the amount of data gathered increases so will the likelihood of the detection of subversive elements prior to the event. Police forces are the first to note that part and parcel of any success in catching people who are not on any database are relations with local communities who inform on anyone acting suspiciously or someone who is new to the neighbourhood but does not mingle or associate with anyone else.

The trends and patterns intelligence methodology, despite being effective 
in such policing and security operations against illicit organised activities and terrorism, has proved to be lacking in determining cataclysmic events within states. The French Revolution of 1789, the Indian Sepoy Revolt of 1856, the numerous coups and revolutions that followed de-colonization, the demise of the Soviet Union, the 9/11 attacks in the United States and the 2004 Madrid train bombings in Spain all attest to this. Being cataclysmic events there was no previous trend or pattern to predict or forecast the event. Such examples show why the 'trends and patterns' methodology has given rise for other methodologies in border security.

One such methodology is that of frequency that is a result of the gathering of data and its analysis. Frequency became the main methodology of analysis of data pertaining to coups and revolutions in the proliferation of independent authoritarian states that emerged after World War II during the period of de-colonisation. Supplementary to the tendency of using the methodology of frequency as intelligence analysis, and indeed part and parcel of the overwhelming success of the methodology, has been the use of computers. Computers have enabled the central collation of data, its interpretation through statistical analysis such as regression models and in plotting results on graphs. These results determine a frequency that could also indicate a trend or a pattern. The peripheral value of computerising the data to ascertain the frequency also assists in the rapid sharing of intelligence with other organisations locally and internationally. This is of value when analyzing data pertaining to border security events such as acts of terrorism, drug trafficking and warlordism.

Hence the two intelligence methodologies, trends and patterns and frequency, are invaluable for border security when utilized in conjunction with each other. For example, taking data and computerising it to ascertain the frequency of terrorist attacks allows for determining a trend and pattern in targets, dates and methods in order to predict or forecast a future attack. This is evident given the nature of fundamentalist terrorist groups whose members are willing to commit suicide as a holy act. It would be a reasonable assumption that there would be an increase in the frequency of such terrorism indicative of an intensification of the terrorist campaign. Moghadam (2003:65-92) describes the numerous suicide bus bombings in Israel as asserting the validity of such an assumption as does the terrorism of the Irish Republican Army striking certain targets at certain times of the year using similar methods.

Segell (2004:81-96) notes the limitation being that neither methodologies of frequency nor 'trends and patterns' are able to determine the specific target unless there is specific information - attested by the 9/11 attacks in the United States and 
the 2004 Madrid Train bombings in Spain. Such attacks are unlikely to see repetition on the same targets by the same means on the same scale. Put bluntly, the 19 perpetrators of the $9 / 11$ attacks died in the act of terrorism when destroying their targets. Similarly the ringleader and main perpetrator of the 2004 Madrid Train bombings, a Tunisian named Sarhane Ben Abdelmajid Fakhet, was among four suicide bombers who died in a police raid on 4 April 42004 on Irene Fernandez Street in the suburb of Leganes, south of Madrid. Nevertheless the value of frequency as an intelligence analysis methodology is to highlight that another terrorist attack, maybe of similar type, is imminent, thereby raising the alert status and efforts to track individuals.

Raising an alert status in border security missions requires effective coordination between all security agencies and forces and indeed the assistance of the public at large for it to be successful. This is because the greater the frequency of acts of terror the more likely that a society will accept terrorism as an acceptable act of politics, albeit extremist, rather than one-off radical militarism. If it reaches such a stage then the acts of criminals or terrorists have changed the texture of society. Such a texture being the way of life that society is willing to accept as a daily routine. The value of intelligence will be diminished temporarily as society disregard security alerts status changes as being significant to their way of life. It will be the acceptable way of life to expect and absorb the acts of terrorism without fear and not act against the acts of terrorism. However, in the longer term this will result in escalation by the terrorist organisation to attain greater effect and greater recognition. This will generate a frequency and a trend or pattern for the intelligence services who could then gain the advantage in earlier detection, prevention and apprehension of the perpetrators.

Davis (1996:35-42) takes this in the perspective of managing uncertainty in intelligence-policy relations showing that in recognising this intelligence services have utilised a third intelligence methodology to achieve effective management of the uncertainty (risk) of maintaining border security in times of escalations and to turn this risk into opportunity. This third methodology of intelligence gathering and analysis is that of probability. Probability is the supposition of a crime or a terrorist event based upon risk analysis of latent threat and target vulnerability. Probability as an intelligence methodology has three possible avenues for implementation. It could be an integral third element in the intelligence methodology of trends and patterns as a subsequent step to confirm the intelligence methodology of frequency. It could be utilised in conjunction with the intelligence methodology of frequency but without that of trends or patterns. It could be an independent step where no other methodology is applicable. 
For example, where intelligence analysis has determined that there is a trend or pattern and that there is frequency then there is a high probability of a border security event. Data gathering and intelligence analysis could focus, for example, on determining trends and patterns in human travel and communication. The success of the methodology of trends and patterns in predicting and/or forecasting the chosen vulnerability would be determined by the frequency of communication pertaining to targets or even the frequency of individuals meeting. Such risk analysis is in coupling trends and patterns methodology determination of threat intent and capability and vulnerability assessment with the methodology of frequency. The subsequent determination of the statistical analysis of prediction and forecasting is in the likelihood or probability of the potential threat turning into an actual event. Hence intelligence analysis of data considers how any form of latent criminal or terrorist capability might result in the basis for moving from one alert status to another.

Alternatively, probability is also a valued methodology in the absence of any trend and pattern or that of any frequency. For example, in the world of fundamentalist non-state terrorism world terror is perpetrated for the sake of terror with no clear political objective to be addressed by states. In the period following a terrorist attack when no evidence suggests a subsequent attack and where the perpetrators have not been apprehended then there is a high risk or a high probability of another attack on vulnerable targets. For example probability as a methodology of border security attained urgency given the migration of the security policy of the United States from threat based to that of vulnerability assessment following the terrorist attack on the USS Cole and later the 9/11 attack. Such terrorist events showed that although it was possible to use precautionary measures such as missile defence to negate the capability of states and state sponsorship terrorism capability there was a necessity for a method of analysis for events that were not state sponsored. Probable targets could consist of urban areas, undefended civilian targets and essential infrastructure such as electrical grids. Rieber (2004:97-112) provides evidence that probability is also the caveat and fall-back safety mechanism for analysts to cover their tracks when they are not certain in their analysis or on the validity of the data for both border defence and for border security.

\section{Conclusion}

These three intelligence methodologies, drawn together, suggest a solution to the main problem facing the armed forces and security services of sovereign states in the $21^{\text {st }}$ Century. This problem, as defined at the start of this article, is the 
inability of the armed forces of a state to protect its citizens against the security threats by organised crime and terrorism that operate with impunity across state borders. The intelligence methodologies are extremely successful given that they define and analyse the causes of the threat and not just the symptoms. The intelligence methodologies go beyond that of the armed forces in posturing of defending a territorially demarcated border. The intelligence methodologies aim to predict, forecast, prevent and pre-empt security threats to individuals within states.

Hence the three intelligence methodologies independently or in conjunction with each other are the most applicable way to resolve the increasingly diverse missions of border defence and border security - each requiring different equipment, forces, training and hence tactics and strategy. In using these three intelligence methodologies a state is able to maintain open borders to further the benefits of globalisation and to reduce the increasing cost of weaponry for the armed forces while enhancing its territorial defence and the security of its citizens.

Integral to the implementation of the three intelligence methodologies for both border defence and border security is the structure of the domestic defence and security organization and regional and global coordination. Such relations require a constant two-way street for the input of further data and the clarification, questioning and revision of existing data. Once these are in place then it is possible to build regional confidence to effect disarmament of weaponry superfluous to territorial conflict such as aircraft, tanks and landmines. This has worked for Europe and it can also work for Africa. Successful intelligence means that the armed forces of each state can be streamlined into elite, mobile and versatile forces in combined and joint task forces with neighbouring states using assault rifles, armored personnel carriers and helicopters. This will assist in facilitating the main border security tasks of preventing and apprehending cross-border violations of smugglers, criminals and terrorists. Confidence instills trust promoting defence and security from whence prosperity emerges.

\section{BIBLIOGRAPHY}

Ackleson, J. (2003) Directions in Border Security Research. The Social Science Journals. 40 (4), 573-581.

Adelman, H. (2002) Refugees and Border Security Post-September 11. Refuge, 20 (4), 5-14.

Agrell, W. and Huldt B. (1983), eds. Clio Goes Spying: Eight Essays on the History 


\section{1}

of Intelligence. Lund, Sweden, Scandinavian University Books.

Austin, S. and Rankov, N.B. (1995) Exploratio: Military and Political Intelligence in the Roman World from the Second Punic War to the Battle of Adrianople. London, Routledge.

Bialer, U. (1980) The Shadow of the Bomber: The Fear of Air Attack and British Politics, 1932-1939. London, Royal Historical Society.

Carter, A.B. (2001) The Architecture of Government in the Face of Terrorism. International Security, 26 (3), 5-23.

Clauser, J.L. and Weir, S.M. (1975) Intelligence Research Methodology: An Introduction to Techniques and Procedures for Conducting Research in Defense Intelligence. State College, PA, H.R.B. Singer.

Cliffe, L. (1999) Regional Dimensions of Conflict in the Horn of Africa. Third World Quarterly - Journal of Emerging Areas, 20 (1), 89-111.

Cumming, A. and Masse, T. (2004) FBI Intelligence Reform Since September 11, 2001: Issues and Options for Congress. Washington, DC, Congressional Research Service.

Davis, J. (1996) The Challenge of Managing Uncertainty: Paul Wolfowitz on Intelligence-Policy Relations. Studies in Intelligence, 39 (5), 35-42.

Duffield, M. (2002) War as a Network Enterprise: The New Security Terrain and its Implications, Cultural Values, 6 (1-2), 153-165.

Dvornik, F. (1974) Origins of Intelligence Services: The Ancient Near East, Persia, Greece, Rome, Byzantium, the Arab Muslim Empires, the Mongol Empire, China, Muscovy. New Brunswick, NJ, Rutgers University Press.

Ermarth, F. (1988) The Role of Analysis. Periscope, 13 (4), 7-11.

Freedman, L. (1981) The Evolution of Nuclear Strategy. London, Macmillan in association with the International Institute for Strategic Studies.

Howard, M. and Parett, P. (1989) ed. Clausewitz on War. Princeton, Princeton University Press. 
Jensen, S. (2004) The Security State and the State of Civil Liberties. Labour, (Canada), 53, 247-256.

Johnston, R. (2005) Analytic Culture in the US Intelligence Community. Washington DC, CIA, The Center for the Study of Intelligence.

Kahn, D. (2001) An Historical Theory of Intelligence. Intelligence and National Security, 16 (3), 79-92.

Kirkpatrick, D. (2004) Lecture at the Royal United Services Institute, London, November 2004 "Government and Industry: Problematic Partnering", http://www.rusi.org/militarysciences//defencesystems/ref:P4198C021618F9/

Maclean, M. (1981) Ten Thousand Day War. New York, St Martins Press.

McCullough, R. (2004) The Future of Transatlantic Co-operation. Washington, SAIC Centre for European Security, CES Monograph Wilton Park.

Mackmurdo, C. (2004) Intelligence: Getting Facts. World Today, 60 (8-9), 23-25.

Mbuh, J.M. (2004) International Law and Conflicts: Resolving Border and Sovereignty Disputes in Africa, London, iUniverse.

Moghadam, A. (2003) Palestinian Suicide Terrorism in the Second Intifada: Motivations and Organizational Aspects. Studies in Conflict and Terrorism, 26 (2), 65-92.

Neilson, K. and McKercher, B.J.C. (1992) eds. Go Spy the Land: Military Intelligence in History. Westport, CT, Praeger.

Orogun, P.S. (2003) Plunder, Predation and Profiteering. Perspectives on Global Development and Technology, 2 (2), 283-313.

Paul, T.V. and Ripsman, N.M. (2004) Under Pressure? Globalisation and the National Security State. Millennium: Journal of International Studies, 33 (2), 355380 .

Pickering, S. (2004) Border Terror: Policing, Forced Migration and Terrorism. Global Change Peace and Security, 16 (3), 211-226. 
Pierik, P. (2003) ed. Tannenberg: Erich Ludendorff and the Defence of the Eastern German Border in 1914. Uitgeverij Aspekt B.V.

Rieber, S. (2004) Intelligence Analysis and Judgmental Calibration. International Journal of Intelligence and Counterintelligence, 17 (1), 97-112.

Roach, A. (2003) Container and Port Security: A Bilateral Perspective. The International Journal of Marine and Coastal Law, 8 (3), 341-361.

Sanchez-Barrio J.M. (2001) ed. The Art of War: Sun-Tsu. Tokyo, Budo International Press.

Segell, G. (2004) Intelligence Agency Relations Between the European Union and the U.S, International Journal of Intelligence and Counterintelligence, 17 (1), 8196.

Sheldon, R. (2002) Espionage in the Ancient World: An Annotated Bibliography of Books and Articles in Western Languages. Jefferson, NC, McFarland.

Shultz, R., Farah D. and Lochard, I. (2004) Armed Groups: A Tier One Security Priority, Denver, US Air Force INSS Occasional Paper 57. 